\title{
Pengaruh Penambahan Serbuk Daun Pepaya (Carica papaya) pada Pakan untuk Meningkatkan Pertumbuhan Ikan Lele (Clarias sp.)
}

\section{The Effect of Adding Papaya Leaf Powder (Carica Papaya) to The Feed to Increase The Growth Of Catfish (Clarias sp.)}

\author{
Muhammad Bangun Mubaraq $^{\left.1^{*}\right)}$, Muhammad Marzuki ${ }^{1)}$, Fariq Azhar ${ }^{1)}$ \\ ${ }^{1}$ Program Studi Budidaya Perairan, Fakultas Pertanian,Universitas Mataram Jl. Pendidikan No \\ 37, Mataram \\ *Corresponding author: mmubaraq06@gmail.com
}

Submitted: 06 January 2021 Revised: 15 April 2021 Accepted: 27 April 2021 Publish: 30 October 2021

\begin{abstract}
Abstrak
Daun pepaya merupakan bahan alami yang sering dimanfaatkan dibidang perikanan air tawar khususnya sebagai pakan tambahan, karena memiliki kandungan enzim yang dibutuhkan oleh ikan. Penelitian ini bertujuan untuk menganalisis pengaruh penambahan serbuk daun pepaya pada pakan untuk meningkatkan pertumbuhan ikan lele (Clarias sp). Pakan yang digunakan pada penelitian ini yaitu pakan komersil dengan kandungan protein $30 \%$ yang ditambahkan serbuk daun pepaya. Serbuk daun pepaya didapatkan dari daun pepaya yang dikeringkan terlebih dahulu sampai benar-benar kering. Setelah kering daun pepaya dihaluskan dengan menggunakan blender. Penelitian dilakukan secara eksperimental menggunakan Rancangan Acak Lengkap (RAL), dengan 4 perlakuan dan 3 ulangan. Perlakuan 1 (P1) sebagai kontrol (tanpa pemberian serbuk daun pepaya), P2 (pakan dengan serbuk daun pepaya $2 \%$ ), P3 (Pakan dengan serbuk daun pepaya 3,5\%), P4 (pakan dengan serbuk daun pepaya 4,2 \%). Parameter pertumbuhan merupakan parameter utama yang diamati pada penelitian ini. Analisis data menggunakan ANOVA untuk meliihat perbedaan pengaruh dari masing masing perlakuan dengan selang kepercayaan 95\% ( $>0.05$ ). Hasil penelitian menunjukan bahwa penambahan serbuk daun pepaya memberikan pengaruh nyata terhadap laju pertumbuhan panjang dan berat $(\mathrm{p}>0.05)$, dimana perlakuan terbaik terdapat pada $\mathrm{P} 3$ dengan pertumbuahan panjang sebesar 2,69 $\mathrm{g}$ dan $3,51 \mathrm{~cm}$, berat dan panjang spesifik 3,89 $\mathrm{g}$ dan $5,89 \mathrm{~cm}$, serta FCR 0,517.
\end{abstract}

Kata kunci: pertumbuhan, serbuk, daun papaya

\begin{abstract}
Papaya leaf is a natural ingredient that is often used in the field of freshwater fisheries, especially as additional feed, because it contains enzymes needed by fish. This study aimed to analyze the effect of adding papaya leaf powder to feed on increasing the growth of catfish (Clarias sp). The feed used in this study was commercial feed with a protein content of $30 \%$ which was added with papaya leaf powder. Papaya leaf powder is obtained from papaya leaves that are dried in the sun until completely dry. After drying, the papaya leaves are mashed using a blender. The study was conducted experimentally using a completely randomized design (CRD), with 4 treatments and 3 replications. Treatment 1 (P1) as control (without giving papaya leaf powder), P2 (feed with papaya leaf powder 2\%), P3 (feed with papaya leaf powder $3.5 \%$ ), P4 (feed with papaya leaf powder $4.2 \%$ ). Growth parameters are the main parameters observed in this study. Data analysis used ANOVA to determine the difference in the effect of each treatment with a 95\% confidence interval ( $p>0.05$ ). The results showed that the addition of papaya leaf powder had a significant effect on the growth rate of length and weight ( $>>0.05)$, where the best treatment was found in P3 with length growth of $2.69 \mathrm{~g}$ and $3.51 \mathrm{~cm}$, specific gravity and length. of $3.89 \mathrm{~g}$ and 5.89 $\mathrm{cm}$, and an FCR of 0.517 .
\end{abstract}

Key words: growth, powder, papaya leaves

\section{PENDAHULUAN}

Sektor perikanan budidaya ikan air tawar di Indonesia memiliki potensi untuk dikembangkan melalui ekstensifikasi maupun intensifikasi.
Adapun komoditas yang biasa dibudidaya adalah ikan lele. permintaan ikan lele cukup tinggi yaitu mencapai \pm 500.000 ekor/minggu di pasar 
domestik (Arief dkk., 2014; Pratama dkk., 2017). Selain itu, ikan ini termasuk komoditas budidaya unggulan air tawar (Nisrinah dkk., 2013). Produksi ikan lele terus mengalami peningkatan sejak tahun 2010 sampai 2013 dari sebesar 242.811 ton meningkat menjadi 758.455 ton (Rahma dkk., 2015). Laju pertumbuhan merupakan faktor penting dalam keberhasilan usaha budidaya perikanan (Haryono dkk., 2015). Meskipun ikan ini termasuk dalam ikan dengan laju pertumbuhan cepat, laju pertumbuhan yang lambat akan menyebabkan lamanya waktu pemeliharaan dan besarnya biaya yang harus dikeluarkan, lamanya waktu pemeliharaan juga akan meningkatkan resiko dalam pemeliharaan, seperti mudah terserang penyakit, kematian masal dan sebagainya.

Selain kualitas air yang optimal, salah satu unsur penting dalam kegiatan budidaya yang menunjang pertumbuhan dan kelangsungan hidup ikan adalah pakan dan teknologi budidaya (Primashita dkk., 2017). Kebutuhan pakan pada kegiatan budidaya ikan lele berkisar antara $60-70 \%$ dari biaya total produksi yang dikeluarkan (Arief $d k k$. 2014). Hal inilah yang menyebabkan pentingnya pakan sehingga perlu dilakukan penelitian untuk memperbaiki nilai nutrisi pakan yaitu dengan penambahan bahan alami seperti daun pepaya. Penambahan serbuk daun pepaya pada pakan komersil mampu memperkaya enzim pada pakan. Penambahan enzim pada pakan dilakukan untuk dapat memanfaatkan protein secara maksimal dan lebih optimal pada kultivan
(Taqwdasbriliani dkk.,2013). Tingginya harga pakan mendorong penggunan bahan lokal untuk dimanfaatkan dalam pakan ikan. Tujuan dari penelitian ini yaitu untuk mengetahui pengaruh penambahan serbuk daun pepaya terhadap pertumbuhan dan kelangsungan hidup ikan lele yang dipelihara pada akuarium.

\section{METODE PENELITIAN}

\section{Waktu dan Tempat}

Penelitian ini dilaksanakan selama 35 hari pada bulan Juli sampai Agustus 2020, bertempat di Desa Langko, Kecamatan Lingsar, Kabupaten Lombok Barat, Provinsi Nusa Tenggara Barat.

\section{Metode Penelitian}

Penelitian ini dilakukan dengan metode eksperimental menggunakan Rancangan Acak Lengkap (RAL). Aspek yang diteliti adalah pengaruh pemberian pakan yang berbeda dengan 4 perlakuan dan 3 kali ulangan, sehingga diperoleh 12 unit percobaan. Dimana, Perlakuan 1 (P1) merupakan kontrol $=($ tanpa pemberian serbuk daun pepaya), Perlakuan $2(\mathrm{P} 2)=$ pakan dengan serbuk daun pepaya $2 \%$, Perlakuan $3(\mathrm{P} 3)=$ pakan dengan serbuk daun pepaya $3,5 \%$, Perlakuan 4 $(\mathrm{P} 4)=$ pakan dengan serbuk daun pepaya $4,2 \%$. Penempatan setiap unit percobaan dilakukan secara acak (Joerakate dkk., 2013).

\section{Prosedur Penelitian}

\section{Persiapan Wadah Pemeliharaan}

Wadah yang digunakan pada penelitian ini yaitu kontainer berukuran $40 \mathrm{~cm}$ x $30 \mathrm{~cm}$. Kontainer yang akan digunakan dibersihkan terlebih dahulu. 
Kontainer yang sudah dibersihkan diatur atau ditata sesuai dengan posisi yang sudah ditentukan. Kemudian diberikan label sesuai dengan perlakuan dan ulangan masing-masing.

\section{Seleksi Ikan Uji dan Penerbaran}

Ikan Lele yang digunakan dalam penelitian ini adalah dalam kondisi tubuh sehat, tidak sakit atau tidak cacat, tidak terdapat luka, pergerakannya aktif, dan bentuk badan proporsional. Penebaran ikan Lele dilakukan setelah melalui tahap seleksi. Padat tebar yang digunakan dalam penelitian ini dan ditebar untuk masing-masing kontener yaitu sebanyak 15 ekor dalam satu wadah.

\section{Jenis Pakan yang Digunakan}

Pakan yang digunakan pada penelitian ini yaitu pakan komersil dengan kandungan protein $30 \%$ yang ditambahkan serbuk daun pepaya. Serbuk daun pepaya didapatkan dari daun pepaya yang dikeringkan terlebih dahulu sampai benar-benar kering. Setelah kering daun pepaya dihaluskan dengan menggunakan blender. Kemudian untuk mendapatkan hasil yang lebih halus diayak menggunakan saringan teh. Aplikasi pemberian pakan menggunakan feeding ratio $5 \%$ dari biomass dengan frekwensi pemberian pakan satu kali. Selanjutnya, penambahan tepung tapioka digunakan untuk merekatkan pakan dan serbuk daun pepaya.

\section{Parameter Penelitian}

\section{Laju Pertumbuhan Spesifik}

Pengukuran laju pertumbuhan panjang dan bobot dilakukan setiap 7 hari sekali selama pemeliharaan dengan mengambil 10 ekor ikan sebagai sampel dari masing masing perlakuan. Penimbangan ikan dilakukan dengan mengambil satu persatu dan ditempatkan di dalam wadah plastik yang berada di atas timbangan analitik dengan ketelitian 0,01 gram. Sedangkan pengukuran panjang ikan penggaris kemudian diamati panjang ikan. Laju pertumbuhan spesifik harian merupakan laju pertambahan bobot individu dalam persen dan dapat dihitung menggunakan rumus (Muchlisin dkk, 2016), adalah sebagai berikut:

Laju Pertumbuhan Berat Spesifik

$$
S G R=\left[\frac{(\operatorname{Ln} W t-\operatorname{Ln} W o)}{t}\right] \times 100 \%
$$

Keterangan:

SGR = Laju pertumbuhan harian (\%)

$\mathrm{Wt}=$ Bobot rata-rata benih di akhir pemeliharaan $(\mathrm{g})$

$\mathrm{Wo}_{\mathrm{o}}=$ Bobot rata-rata benih di awal pemeliharaan $(\mathrm{g})$

$\mathrm{t}=$ Lama waktu pemeliharaan (hari)

Laju Pertumbuhan Panjang Spesifik

$$
L G R=\left[\frac{(\operatorname{Ln} L t-L n L o)}{t}\right] \times 100 \%
$$

Keterangan:

LGR = Laju pertumbuhan harian

$$
\text { (LGR) }
$$

Lt =Panjang rata-rata benih di akhir pemeliharaan $(\mathrm{g})$

Lo = Panjang rata-rata benih di awal pemeliharaan $(\mathrm{g})$

$\mathrm{t}$ = Lama waktu pemeliharaan (hari) 


\section{Laju Pertumbuhan Mutlak}

Laju pertumbuhan mutlak selama pemeliharaan dihitung menggunakan rumus Hartini $d k k$., (2013) adalah sebagai berikut:

Pertumbuhan Berat Mutlak

$$
\mathrm{W}=\mathrm{Wt}-\mathrm{Wo}_{\mathrm{o}}
$$

Keterangan :

$\mathrm{W}=$ Pertumbuhan berat mutlak ikan yang dipelihara (g)

$\mathrm{Wt}=$ Berat ikan pada akhir $(\mathrm{g})$

$\mathrm{Wo}=$ Berat ikan pada awal $(\mathrm{g})$

Pertumbuhan Panjang Mutlak

$$
\mathbf{L}=\mathbf{P t}-\mathbf{P o}
$$

Keterangan:

$\mathrm{P}=$ Pertumbuhan panjang mutlak ikan yang dipelihara $(\mathrm{cm})$

$\mathrm{Pt}=$ Panjang ikan pada akhir $(\mathrm{cm})$

$\mathrm{Po}=$ Panjang ikan pada awal $(\mathrm{cm})$

\section{Tingkat Kelangsungan Hidup (Survival Rate)}

Penentuan kelangsungan hidup dilakukan dengan menghitung seluruh kematian biomass dari masing - masing perlakuan selama penelitian (35 hari). Tingkat kelangsungan hidup ikan selama pemeliharaan dihitung menggunakan rumus Hartini $d k k$., (2013) adalah sebagai berikut:

$$
S R=\frac{N t}{N o} \times 100 \%
$$

Keterangan:

$\mathrm{SR}=$ Kelangsungan hidup $(\%)$

$\mathrm{Nt}=$ Jumlah ikan pada akhir (ekor)

$\mathrm{No}=$ Jumlah ikan pada awal (ekor)

\section{Rasio Konversi Pakan (FCR)}

FCR dapat dihitung menggunakan rumus Septian $d k k$. , (2013) adalah sebagai berikut:

$$
F C R=\frac{F}{(W t+d)-W o}
$$

Keterangan:

$\mathrm{FCR}=$ Food Conversion Ratio

$\mathrm{Wt}=$ Berat ikan pada akhir penelitian

(g)

Wo $=$ Berat ikan pada awal penelitian

(g)

$\mathrm{F}=$ Jumlah pakan yang dikonsumsi $(\mathrm{g})$

\section{Analisis data}

Analisis data yang dilakukan dalam penelitian ini meliputi pertumbuhan spesifik, pertumbuhan mutlak, kelangsungan hidup (survival rate), rasio konversi pakan (FCR), efisiensi pemanfaatan pakan, dan kualitas air. Data yang diperoleh diuji menggunakan Analysis of Variance (ANOVA) pada taraf kepercayaan $95 \%$ dengan program SPSS untuk mengetahui pengaruh dari setiap perlakuan. Apabila hasil analisis statistik menunjukkan pengaruh yang berbeda nyata, maka dilakukan uji lanjut BNT untuk mengetahui perlakuan terbaik.

\section{HASIL DAN PEMBAHASAN}

Pertumbuhan Berat Mutlak

Pertumbuhan berat mutlak tertinggi terletak pada P3 (Pakan $+4,2 \%$ serbuk daun pepaya) sebesar 2,69 gram, diikuti dengan P2 (pakan $+3,5 \%$ serbuk daun pepaya) sebesar 1,72 gram, kemudian P1 (Pakan $+2 \%$ serbuk daun pepaya) sebesar 1,64, sedangkan kontrol (P1) sebesar 0,75 (Gambar 1a). Pemberian serbuk daun pepaya memberikan pengaruh signifikan $(\mathrm{P}>0,05)$ terhadap pertumbuhan berat mutlak dengan perlakuan terbaik yaitu penambahan serbuk daun pepaya sebanyak $4,2 \%$ (2.69 c \pm 0.13$)$. Hal ini menunjukkan kandungan enzim papain dalam daun 
pepaya bekerja optimal dalam membantu mencerna pakan yang diberikan. Enzim yang terdapat dalam pepaya mampu mempercepat proses pencernaan sehingga nutrient lebih cepat terserap dan cukup tersedia sehingga dapat meningkatkan pertumbuhan benih ikan (Widaryati, 2018).

\section{Pertumbuhan Panjang Mutlak}

Nilai pertumbuhan panjang mutlak tertinggi yaitu pada perlakuan P3 (Pakan $+4,2 \%$ serbuk daun pepaya) sebesar $3,52 \mathrm{~cm}$, diikuti oleh perlakuan P2 (pakan $+3,5 \%$ serbuk daun pepaya) sebesar 3,06 cm, kemudian perlakuan P1 (Pakan $+2 \%$ serbuk daun papaya) sebesar 2,99 cm, untuk kontrol sebesar $2,21 \mathrm{~cm}$ (Gambar 1b). Pemberian serbuk daun papaya memberikan pengaruh signifikan $(\mathrm{P}>0,05)$ terhadap pertumbuhan panjang mutlak dengan perlakuan terbaik yaitu dengan penambahan serbuk daun pepaya $4,2 \%$ $\left(3.51^{\mathrm{c}} \pm 0.24\right)$.
Berdasarkan grafik tentang pertumbuhan panjang mutlak ikan lele, diketahui bahwa perlakuan P3 memiliki nilai pertumbuhan tertinggi, karena dosis perlakuan P3 dapat meningkatkan pertumbuhan panjang mutlak dari ikan lele yang dipelihara selama 35 hari. Hal ini karena dosis dari perlakuan 3 memiliki kemampuan yang lebih baik dalam merombak pakan menjadi unsur yang lebih sederhana dibandingkan dengan perlakuan lain. Hal ini sesuai dengan pendapat Khodijah $d k k$., (2015) yang menyatakan bahwa ikan dapat memanfaatkan pakan yang diberikan dengan baik karena didukung oleh aktivitas protease papain dalam papaya yang dicampurkan dalam pakan, sehingga proses perombakan pakan menjadi unsur-unsur yang lebih sederhana akan lebih banyak, Unsurunsur sederhana yang lebih banyak inilah, maka sintesa asam amino untuk menjadi protein tubuh juga lebih besar, sehingga pertambahan bobot akan lebih besar pula.

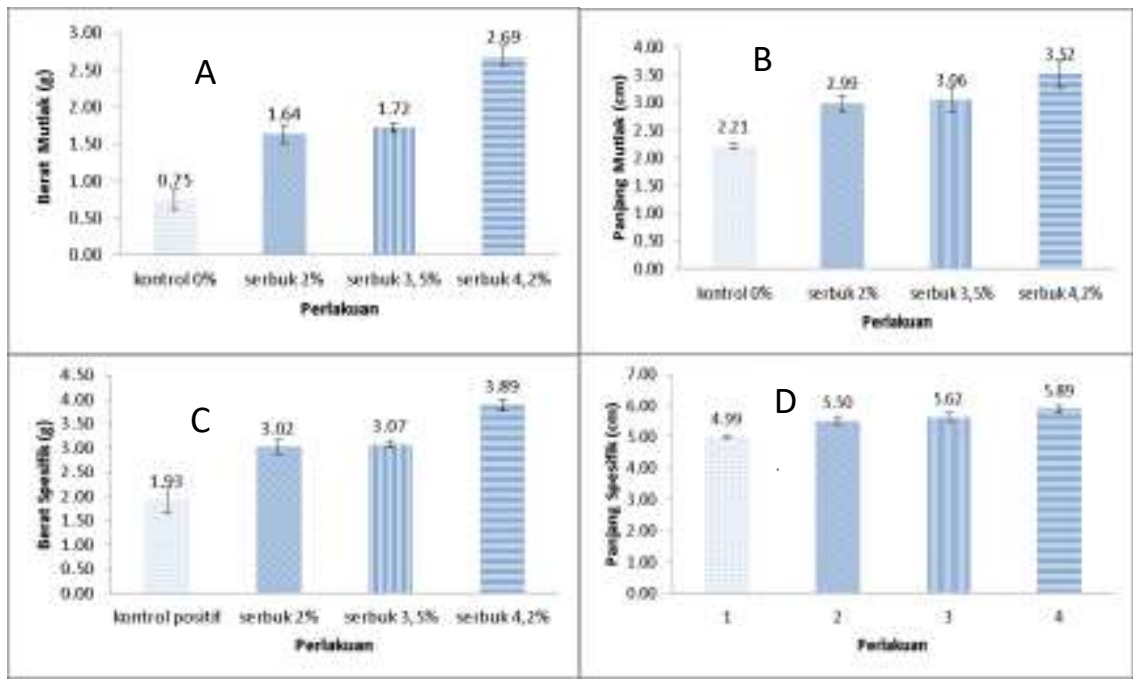

Gambar 1. a:Pertumbuhan berat mutlak, b: Pertumbuhan panjang mutlak, c: Pertumbuhan berat spesifik, d: Pertumbuhan panjang spesifik 


\section{Pertumbuhan Berat Spesifik}

Nilai pertumbuhan berat spesifik tertinggi yaitu pada perlakuan (Pakan $+4,2 \%$ serbuk daun pepaya) sebesar 5,43 gram, diikuti dengan (pakan + $3,5 \%$ serbuk daun pepaya) sebesar 4,35 gram, kemudian (pakan $+2 \%$ serbuk daun papaya) sebesar 4,37gram, untuk kontrol sebesar 2,70 gram (Gambar 1c). Secara statistik pemberian serbuk daun pepaya memberikan pengaruh signifikan $\quad(\mathrm{P}>0,05) \quad$ terhadap pertumbuhan berat spesifik dengan perlakuan terbaik yaitu dengan penambahan serbuk daun pepaya $4,2 \%$ (3.89 c \pm 0.10$)$. Laju pertumbuhan berat spesifik berkaitan erat dengan pertambahan berat tubuh ikan yang berasal dari pakan yang dikonsumsi. Perbedaan nilai laju pertumbuhan spesifik pada setiap perlakuan diduga karena adanya pengaruh pemberian serbuk daun pepaya pada pakan, ikan dapat memanfaatkan pakan yang diberikan dengan baik karena didukung oleh aktivitas enzim papain dalam pakan yang ditambahkan serbuk daun pepaya, sehingga proses perombakan pakan menjadi unsur-unsur yang lebih sederhana akan lebih banyak dan lebih cepat terjadi. Menurut Isnawati (2015), sebelum terjadinya pertumbuhan, kebutuhan energi untuk pemeliharaan harus dipenuhi terlebih dahulu. Hal ini menunjukkan ikan lele dapat memanfaatkan pakan yang diberikan dengan baik karena didukung aktivitas protease papain dalam pakan.

Pertumbuhan Panjang Spesifik

Nilai pertumbuhan panjang Spesifik tertinggi yaitu pada perlakuan
P3 (Pakan $+4,2 \%$ serbuk daun pepaya) sebesar $1,93 \mathrm{~cm}$, diikuti dengan $\mathrm{P} 2$ (pakan $+3,5 \%$ serbuk daun pepaya) sebesar 1,74 cm, kemudian P1 (Pakan $+2 \%$ serbuk daun papaya) sebesar 1,78 $\mathrm{cm}$, untuk kontrol sebesar $1,40 \mathrm{~cm}$ (Gambar 1d). Pemberian serbuk daun papaya memberikan pengaruh signifikan $\quad(\mathrm{P}>0,05) \quad$ terhadap pertumbuhan panjang spesifik dengan perlakuan terbaik yaitu dengan penambahan serbuk daun pepaya sebanyak 4,2\% (5.89 c \pm 0.12$)$. Laju pertumbuhan panjang spesifik berkaitan erat dengan pertambahan panjang tubuh ikan yang berasal dari pakan yang dikonsumsi. Perbedaan nilai laju pertumbuhan spesifik pada setiap perlakuan diduga karena penambahan serbuk daun pepaya mampu untuk lebih cepat memecah protein menjadi asam amino sehingga akan mudah dicerna oleh tubuh ikan. Semakin cepat ikan mencerna asam amino maka pertumbuhan ikan akan bisa semakin cepat.

Menurut Sari dkk. (2018) menyatakan bahwa papain yang terkandung dalam getah pepaya merupakan enzim proteolitik yang mampu menghidrolisis protein menjadi asam amino, semakin banyak enzim papain yang ditambahkan kedalam pakan, maka akan menghasilkan lebih banyak protein yang dihidrolisis menjadi asam amino sehingga protein dalam pakan lebih banyak diserap oleh ikan serta energi yang diperoleh lebih banyak. Pemberian dosis yang tepat sangat penting dikarenakan dengan dosis yang tepat maka proses pemecahan protein akan semakin 
optimal, semakin cepat protein tersebut dipecah menjadi bentuk yang sederhana maka akan semakin cepat juga penyerapan asam amino tersebut di dalam tubuh.

\section{FCR (Food Convertion Ratio)}

Nilai FCR terendah yaitu pada perlakuan P3 (Pakan $+4,2 \%$ serbuk daun pepaya) sebesar 0,517 , diikuti dengan P2 (Pakan $+3,5 \%$ serbuk daun pepaya) sebesar 0,67, kemudian P1 (Pakan $+2 \%$ serbuk daun pepaya) sebesar 0,693, untuk kontrol sebesar 0,957. Pemberian serbuk daun pepaya memberikan pengaruh signifikan $(\mathrm{P}>0,05)$ terhadap FCR dengan perlakuan paling baik yaitu dengan penambahan serbuk daun pepaya $4,2 \%$ (0.51 c \pm 0.022). Nilai FCR yang semakin kecil menunjukkan pakan yang dikonsumsi oleh ikan lebih efisien digunakan untuk pertumbuhan, sebaliknya nilai FCR yang semakin besar menunjukkan pakan yang dikonsumsi kurang efisien (pemanfaatan pertumbuhan rendah) (Amalia, 2013).

Pada penelitian yang dilakukan semakin tinggi dosis serbuk daun papaya yang digunakan mengakibatkan nilai FCR mengalami penurunan. Hal ini menunjukkan bahwa serbuk daun papaya pada penelitian berpengaruh terhadap kualitas pakan yang ditambahkan bahan alami seperti papaya. Menurut Listiowati dan Pramono (2014), semakin kecil nilai FCR berarti pakan semakin berkualitas, hal ini menunjukkan bahwa jumlah pakan yang dikonsumsi lebih besar dari pada jumlah pakan yang tersisa. Nilai
FCR masih dianggap efisien apabila kurang dari 3.

Pada seluruh Perlakuan 1 dan 2 memiliki nilai FCR dibawah 3 sehingga masih efisien dibandingkan dengan perlakuan yang lain. Nilai FCR sangat berkaitan dengan tingkat efisiensi pakan selama peroses pemeliharaan yang dilakukan. Semakin tinggi nilai efisiensi pakan maka akan semakin tinggi pula laju pertumbuhan dari Ikan lele, sehingga akan memudahkan ikan dalam menyerap pakan yang ada dalam saluran pencernaan kemudian akan berpengaruh pada pertumbuhan ikan (Supriyanto, 2010). Menurut Yuriana $d k k$., (2017), mengatakan bahwa serbuk daun pepaya mengandung enzim papain, dimana enzim tersebut kemudian digunakan untuk perombakan protein menjadi asam amino sehingga dapat lebih cepat terserap oleh usus.

\section{Kualitas Air}

Kualitas air pada media pemeliharaan merupakan salah satu faktor penentu keberhasilan dalam budidaya. Pengukuran kualitas air dilakukan sebanyak lima kali yaitu sebelum penebaran, hari ke -7, 14, 21, 29 dan hari ke-35. Adapun parameter kualitas air yang diukur dapat dilihat pada (Tabel 1). Kisaran nilai kualitas yang diperoleh selama penelitian yaitu $\mathrm{pH}$ berkisar antara 7,4 - 7,6, kandungan oksigen terlarut (DO) berkisar antara 4,5 - $5 \mathrm{mg} / \mathrm{l}$,dan suhu berkisar antara $27-29^{\circ} \mathrm{C}$. Nilai kualitas air tersebut menunjukkan bahwa ikan lele dipelihara dalam lingkungan yang masih layak dan sesuai untuk tempat hidupnya. Hal ini juga didukung oleh pernyataan (Taufik, 
2013), yang menyatakan bahwa suhu air sangat berpengaruh terhadap laju metabolisme dan pertumbuhan organisme air. Kisaran suhu optimal bagi kelangsungan hidup ikan lele yaitu $20^{\circ} \mathrm{C}$. Serta pernyataan dari Widiastuti (2009), yang menyatakan bahwa pH air untuk kegiatan budidaya berkisar antara 6-9. Apabila $\mathrm{pH}$ rendah maka oksigen terlarut akan berkurang sehingga konsumsi oksigen pada ikan akan menurun, selera makan berkurang dan aktivitas pernafasan akan naik. Begitupun sebaliknya dengan suasana basa, maka $\mathrm{pH}$ yang optimal untuk perairan berkisar antara $6,5-8,5$.

\section{Kelangsungan Hidup Ikan Lele}

Tingkat kelangsunganhidup ikan lele sebelum disuntikkan tertinggi pada kontrol sebesar $80 \%$, selanjutnya pada perlakuan

P1 (Pakan $+2 \%$ serbuk daun pepaya) dan P2 (Pakan $+3,5 \%$ serbuk daun papaya) sebesar 75,56 \% untuk perlakuan P3 (Pakan $+4,2 \%$ serbuk daun pepaya). Pemberian serbuk daun papaya tidak memberikan pengaruh signifikan $\quad(\mathrm{P}<0,05) \quad$ terhadap kelangsunganhidup ikan lele. Kematian ikan pada penelitian diduga terjadi karena suhu yang rendah pada mingguminggu awal yang mencapai kisaran 14 - $16^{\circ} \mathrm{C}$ sehingga menyebabkan sistem imun ikan menjadi melambat dan menyebabkan kematian pada ikan lele. Menurut Setyowati (2018), yang mengatakan bahwa ikan merupakan hewan berdarah dingin, karena sifat dari ikan tersebut maka sistem imun spesifiknya lebih lambat terhadap suhu yang dingin. Selain itu, menurut pendapat Afdola (2018), menyatakan bahwa tingkat kelangsungan hidup $\geq$ $50 \%$ tergolong baik, 30 - 50\% sedang dan untuk kelangsungan hidup kurang dari 30\% dikatakan tidak baik. Angka kelulushidupan Ikan lele dalam penelitian ini yang berkisar antara 73,33 - $80 \%$, termasuk dalam kategori yaang cukup baik. Selain itu, kematian pada ikan juga dapat disebabkan karena ikan stres yang disebabkan oleh pemindahan lingkungan yaitu dari alamnya ke wadah penelitian. Adapun ciri-ciri ikan yang mengalami stres yaitu lemas (pergerakan yang lambat) tidak merespon pakan yang diberikan, dan berenang kepermukaan. Noviana dkk, (2014), mengatakan bahwa ikan yang mengalami gangguan fisiologis (stress) akan mengakibatkan turunnya nafsu makan ikan secara drastis dan akan sulit bagi ikan untuk beraktivitas seperti berenang dan bernafas. Tingkat kelangsungan hidup dapat dipengaruhi oleh faktor internal dan eksternal dari ikan, tetapi dapat dipastikan bahwa daya toleransi setiap ikan berbeda-beda pada setiap wadah perlakuan, dikarenakan tidak semua Ikan lele yang dipelihara mengalami kematian.

\section{KESIMPULAN}

Pemberian serbuk daun pepaya yang ditambahkan pada pakan dengan dosis tertentu berpengaruh nyata terhadap pertumbuhan berat dan panjang mutlak 2,69 g dan $3,51 \mathrm{~cm}$, berat dan panjang spesifik $3,89 \mathrm{~g}$ dan $5,89 \mathrm{~cm}$, FCR 0,517. Akan tetapi tidak memberikan hasil yang signifikan terhadap kelangsungan hidup benih Ikan lele atau tidak berpengaruh nyata. 


\section{DAFTAR PUSTAKA}

Afdola, Indra S, Adelina. 2018. Pengaruh Penambahan Probiotik dalam Pakan terhadap Pertumbuhan Benih Ikan Bawal Air Tawar (Colossoma macropomum). Jurnal Perikanan, 2 (3) 1-11.

Agustin, R., Ade, D. S. , Yulisman. 2014. Konversi Pakan, Laju Pertumbuhan, Kelangsungan Hidup dan Populasi Bakteri Benih Ikan Gabus (Channa striata) yang Diberi Pakan dengan Penambahan Probiotik. Jurnal Akuakultur Rawa Indonesia, 2(1) :55- 66

Amalia, R., Subandiyono., Endang, A. 2013. Pengaruh Penggunaan Papain terhadap Tingkat Pemanfaatan Protein Pakan dan Pertumbuhan Lele Dumbo (Clarias gariepinus). Journal of Aquaculture Management and Technology, 2 (1) : 136-143

Arief, M., Nur, F., Sri, S. 2014. Pengaruh Pemberian Probiotik Berbeda pada Pakan Komersial terhadap Pertumbuhan dan Efisiensi Pakan Ikan Lele Sangkuriang (Clarias sp.). Jurnal Ilmiah Perikanan dan Kelautan, 6 (1) : 49-53

Arinindita, N. 2014. Pemanfaatan Ekstrak Daun Ketapang Terminalia cattapa untuk Pemcegahn dan pengobatan Ikan Patin Pangasionodon hypopthalmus yang Terinfeksi Aeromonas hydrophila. Skripsi. Institusi Pertanian Bogor, Bogor.

Dharmarathna SLCA, Wickramasinghe S,Waduge RM, Rajapakse RPVJ, KularatneSAM. 2013. Does Carica papaya Leaf-extract Increase The Platelet Count An Experimental Study in a Murine Model.Asian Pac J Trop Biomed, 3(9): 720-724.

Fransiska., D. Rachmawati dan I. Samidjan. 2013. Pengaruh Persentase Jumlah Pakan Buatan Yang Berbeda Terhadap Pertumbuhan dan Kelulushidupan Keong Macan (Babylonia spirata L.). Jurnal Of Aquaculture Management and Technology, 2 (4) : 122-130

Hartini, S., Ade Dwi S., dan Ferdinand H. T. 2013. Kualitas Air, Kelangsungan Hidup dan Pertumbuhan Benih Ikan Gabus (Channa striata) Yang Dipelihara Dalam Media Dengan Penambahan Probiotik. Jurnal Akuakultur Rawa Indonesi, 1 (2) : 192-202

Haryono, H. Noviyani., Pinandoyo., dan D. Chilmawati. 2015. Pengaruh Pakan Buatan Dengan Tepung Ikan Petek Terhadap Pertumbuhan dan
Kelulushidupan Ikan Nila Strain Larasati (Oreochromis niloticus). Journal of Aquaculture Management and Technology, 4 (1): 64-70

Isnawati, N., Romziah, S.,Gunanti, M. 2015. Potensi Serbuk Daun Pepaya Untuk Meningkatkan Efisiensi Pemanfaatan Pakan, Rasio Efisiensi Protein dan Laju Pertumbuhan Relatif pada Budidaya Ikan Nila (Oreochromis niloticus). Jurnal Ilmiah Perikanan dan Kelautan, 7 (2): 103-110

Joerakate W, Yenmak S, Senanan W, Tunkijjanukij S, Koonawootrittriron S, Poompuang S. 2018. Growth performance and genetic diversity in four strains of Asian sea bass, Lates calcarifer (Bloch, 1790) cultivated in Thailand. Agriculture and Natural Resources, 5(2) : 93-98.

Karimah, U., Istyanto Samidjan., dan Pinandoyo. 2018. Performa Pertumbuhan dan Kelulushidupan Ikan Nila Gift (Oreochromis niloticus) yang Diberi Jumlah Pakan Yang Berbeda. Journal Of Aquaculture Management and Technology, 7 (1) : 128-135

Kordi, M.G.H.K. 2013. Panduan Lengkap Memelihara Ikan Air Tawar Lily Publisher: Semarang

Kordi, M.G.H.K. 2007. Meramu Pakan untuk Ikan Karnivora. Lily Publisher: Semarang

Listiowati, E., T.B. Pramono. 2014.Potensi pemanfaatan daun singkong (Manihot utillisima) terfermentasi sebagai bahan pakan ikan nila (Oreochromis sp).Berkala Perikanan Terubuk, 42(2): 63-70.

Muchlisin, Z.A., Ahmad, D., Rina, F., Muhammadar., Musri, M. 2016. Pengaruh Beberapa Jenis Pakan Alami terhadap Pertumbuhan dan Kelulusanhidup Ikan Lele Dumbo (Clarias gariepinus). Jurnal Biolog, 3 (2) : 105-113

Mones RA. 2008. Gambaran Darah Pada Ikan Mas (Cyprinus carpio linn) Strain Majalaya yang Berasal dari Daerah Ciampea Bogor. Skripsi.Fakultas Kedokteran Hewan Institut Pertanian Bogor, Bogor.

Nisrinah., Subandiyono., Tita, E. 2013. Pengaruh Penggunaan Bromelin Terhadap Tingkat Pemanfaatan Protein Pakan Dan Pertumbuhan Lele Dumbo (Clarias Gariepinus). Journal of 
Journal of Aquaculture Science

DOI: https://doi.org/10.31093/joas.v6i2.141

Aquaculture Management and Technology, 2 (2) : 57-63

Nugroho, E. 2013. Lele Peluang Bisnis dan Kisah Sukses. Agriflo: Jakarta

Noviana, P., Subandiyono., Pinandoyo. 2014. Pengaruh Pemberian Probiotik dalam Pakan Buatan Terhadap Tingkat Konsumsi Pakan dan Pertumbuhan Benih Ikan Nila (Oreochromis niloticus). Journal of Aquaculture Management and Technology, 3 (4) : 183-190

Pratama, W. D., \& Manan, A. (2017). Pengaruh Pemberian Probiotik Berbeda dalam Sistem Akuaponik terhadap Kualitas Air pada Budidaya Ikan Lele (Clarias sp.). Journal of Aquaculture Science, 1(1), 27-35.

Primashita, A. H., \& Rahardja, B. S. (2017). Pengaruh Pemberian Probiotik Berbeda dalam Sistem Akuaponik terhadap Laju Pertumbuhan dan Survival Rate Ikan Lele (Clarias sp.). Journal of Aquaculture Science, 1(1), 1-9

Rahma, F.W., Gunanti, M., Laksmi, S. 2015. Pengaruh Pemberian Ekstrak Sargassum sp. dengan Pelarut Metanol pada Pakan terhadap Jumlah Eritrosit dan Diferensial Leukosit Ikan Lele Dumbo (Clarias gariepinus). Jurnal Ilmiah Perikanan dan Kelautan, 7 (2): 53-58

Septian. R., I. Samidjan., dan D. Rachmawati. 2013. Pengaruh Pemberian Pakan Ikan Rucah dan Buatan Yang Diperkaya Vitamin E Terhadap Pertumbuhan dan Kelulushidupan Kepiting Soka (Scylla paromamosain). Journal of Aquaculture Management and Technolog,. 2 (1) : 1324

Selano, D. A. J., J. Nathan., Pr. A. Uneputty., dan Y. A. Lewerissa. 2013. Analisis
October 2021 Vol 6 (2): 83-92

Online pada http://joas.co.id

Beberapa Parameter Kualitas Air di Daerah Habitat Teripang. Jurnal TRITON, 9 (1): 1-9

Supriyanto. 2010. Pengaruh Pemberian Probiotiik Dalam Pelet Terhadap Pertumbuhan Mas Sangkuriang. Pengaruh Pemberian Serbuk daun pepaya $8(1), 17-25$

Taqwdasbriliani, E.B., Johannes, H., Endang, A. 2013. Pengaruh Kombinasi Enzim Papain dan Enzim Bromelin terhadap Pemanfaatan Pakan dan Pertumbuhan Ikan Kerapu Macan (Epinephelus fuscogutattus). Journal of Aquaculture Management and Technology, 2 (3) : 7685

Taufik, M. 2013. Cara Sukses Memulai dan Menjalankan Usaha Ternak Lele. Trans Idea Publishing: Jogjakarta

Utami, Windu Puji. 2009. Efektivitas Ekstrak Paci-Paci Leucas lavandulaefolia Yang Diberikan Lewat Pakan Untuk Pencegahan dan Pengobatan Penyakit MAS Motile Aeromonas septicemia Pada Ikan Lele Dumbo Clarias sp. Skripsi. Fakultas Perikanan dan Ilmu Kelautan Institut Pertanian Bogor

Widiastuti, R.M. 2009. Pertumbuhan dan Kelangsungan Hidup (Survival Rate) Ikan Mas (Cyprinus carpio) yang Dipelihara dalam Wadah Terkontrol dengan Padat Penebaran yang Berbeda. Media Litbang Sulteng, 2 (2): 126-130

Yuriana L., H. Santoso, dan A. Susanto. 2017. Pengaruh probiotik strain Lactobacillus terhadap laju pertumbuhan dan efisiensi pakan lele masamo (Clarias sp.) tahap pendederan I. Jurnal Lentera Pendidikan, 2(1): 12-22 